\title{
Antibacterial mechanism of apple phloretin on physiological and morphological properties of Listeria monocytogenes
}

\author{
Pengtao $\mathrm{ZHAO}^{1,2,3 \#}$, Ying ZHANG ${ }^{1 *}$, Hong DENG ${ }^{1,2,3}$, Yonghong $\mathrm{MENG}^{1,2,3 *}$
}

\begin{abstract}
Green bactericides are excellent strategies for reducing food spoilage. Phloretin was regarded as efficient, broad-spectrum and safe preservative, which showed enormous potential in food industry. Inhibitory mechanism of phloretin on Listeria monocytogenes was systematically elucidated through integrity of cell membrane, intracellular protein content, energy level, and nucleic acid morphological character. SEM and TEM results showed minimal injury of cell membrane, which was further proved by a leakage of potassium ions, ATP and little protein and nucleic acid. There were drastic reduction of intracellular or total protein and ATP compared to cell without phloretin treatment. However, the specific activity of hexokinase and isocitrate dehydrogenase were unaffected after phloretin treatment. From these results, we concluded that phloretin's bacteriostatic mechanism is decreasing the intracellular protein content and energy level resulting from DNA aggregation. This finding was prospective to fully illustrate the phloretin's mechanism and develop it into a natural preservative in food industry.
\end{abstract}

Keywords: apple phloretin; Listeria monocytogenes; antibacterial mechanism; preservative.

Practical Application: Understanding the antibacterial mechanism of apple phloretin on Listeria monocytogenes could provide a theoretical basis for the developing high-performance and low-toxicity antibacterial food preservatives.

\section{Introduction}

Food poisoning and food spoilage caused by microorganism are the most important issues for the food industry. Chemical synthetic preservative applied in food industry to control foodborne pathogens, may cause various hazards to the health of human being (Schuh et al., 2020). With the overuse of antibiotics and transmission of resistance within and between individuals of microorganisms, antibiotic resistance has reached crisis point around the world (Chávez-Martínez et al., 2019; Martens \& Demain, 2017; Vanderhaeghen \& Dewulf, 2017). There is an urgent need to find new antibiotic derivatives. Research into efficient natural antimicrobials such as polyphenols is thought a necessary and potential strategy to overcome this problem.

For the past several decades, natural agents exhibiting antibacterial properties such as polyphenols have been attracting increasing attention. Polyphenols were reported to possess a broad antimicrobial spectrum against microorganisms, including yeast, fungi, bacterium, and even molds (Moreno et al., 2006; Orhan et al., 2010; Zola et al., 2019). As regard to certain class of polyphenols, the antimicrobial properties have been proposed either to develop innovative therapies for the treatment of various microbial infections (Rizvi \& Saleh, 2018; Saavedra et al., 2010), or to develop new food preservatives (Alonso \& Kabuki, 2019; Bouarab Chibane et al., 2019; Zavareh et al., 2020; Wang et al., 2019a). Moreover, the functional compounds of flavonoids are also regarded as a starting point for the development of optimal derivatives in traditional pharmaceutical industry owing to their interesting pharmacological activities (Havsteen, 2002).

Among numerous flavonoids, phloretin belongs to the dihydrochalcones class, a type of polyphenol found in plants, particularly in the bark, leaves, and fruit of apple trees (Chang et al., 2012). It is known to exert a wide variety of biological activities such as anti-inflammatory, antioxidant, and anticancer activities (Chang et al., 2012; Ng et al., 2019; Wang et al., 2019b). The antimicrobial activity of phloretin has been studied and variable results have been reported on different microbial species. As early as 1952, MacDonald \& Bishop (1952) reported that phloretin inhibited the growth of a number of Gram-positive and Gramnegative bacteria, and it was more active against Gram-positive organisms. Shim et al. (2010) reported that phloretin $(500 \mu \mathrm{g} / \mathrm{mL})$ showed in vitro antifungal activity against some plant pathogenic fungi including Phytophthora capsici, Alternaria panax, Sclerotinia sclerotiorum, $R$. solani AG4, and M. grisea on rice on rice and tomato seedlings. Barreca et al. (2014) found that, in apple and kumquat, phloretin was particular active against Gram positive bacteria, in particular S. aureus ATCC 6538, L. monocytogenes ATCC 13932 and MRSA clinical strains with the MIC being between 7.81 and $125 \mu \mathrm{g} / \mathrm{mL}$. Meanwhile, their work has found that phloretin exerted its antimicrobial activity by inhibiting energetic metabolism. Although the biochemical mechanism of phloretin against cell growth inhibition has been studied,

${ }^{1}$ College of Food Engineering and Nutritional Science, Shaanxi Normal University, Chang'an, Xian, P.R. China

${ }^{2}$ Engineering Research Center of High Value Utilization of Western China Fruit Resources, Ministry of Education, Shaanxi Normal University, Chang'an, Xi'an, P.R. China

${ }^{3}$ National Research \& Development Center of Apple Processing Technology, Shaanxi Normal University, Chang'an, Xi'an, P.R. China

"These two authors contributed equally to this paper.

*Corresponding author: mengyonghong@snnu.edu.cn 
this information is still limited. The antibacterial mechanism of phloretin is far from clear.

According to our previous work (Wang et al., 2019a), phloretin $(400 \mu \mathrm{g} / \mathrm{mL})$ shows good capacity on keeping the quality of salmon fillets through decreasing the microbial community diversity, biogenic amines formation, and lipid oxidation. Our another work (Wang et al., 2019b) proved that phlorizin and its oxidation product 2 (POP2) inhibits proliferation and differentiation of 3T3-L1 preadipocytes by decreasing adipocyte viability and restraining the accumulation of intracellular triglycerides.

In this paper, Lister monocytogenes CMCC54004 (Grampositive bacterium), based on reported sensitivity of the tested food-borne pathogens, was selected as the model organism to elaborate the antibacterial mode of action of phloretin. The antibacterial activity of phloretin (concentrations ranging from 25 to $200 \mu \mathrm{g} / \mathrm{mL}$ ) against the representative strain was evaluated by viable cell population. The potential antibacterial mechanisms were determined by permeability and integrity of cell membrane, ATP content, key metabolic enzymes activity, intracellular protein content as well as nucleic acid morphological character. Our work systematically provides a new insight into phloretin's antibacterial mechanism of action compared with the reported findings. The results could provide a theoretical basis for the developing of phloretin into high-performance and low-toxicity antibacterial food preservative.

\section{Materials and methods}

\subsection{Chemicals and standard solution}

Standard compounds of phloretin (PubChem CID: 4788) of $>96 \%$ purity was purchased from Healthful Biotechnology Co. Ltd (Xian, China), which were extracted and purified from thinned young apples. Dimethyl sulfoxide (DMSO) was supplied by Sigma Aldrich (Shanghai, China). Tryptone soy broth (TSB) and agar were from Beijing Aoboxing Bio-tech Co. Ltd. (Beijing, China). Other chemicals used were all of analytical grade.

Phloretin stock solution was prepared in DMSO, then was subsequently diluted to appropriate working concentrations. The final concentration of DMSO in growth medium was below $1 \%(\mathrm{~V} / \mathrm{V})$, a level at which DMSO was considered not to affect the bacterial growth based on preliminary experiments.

\subsection{Bacterial strain and growth condition}

L.monocytogenes CMCC54004 (obtained from National Centre for Medical Culture Collections, Beijing, China) was used throughout this study. Cells were stored at $-80^{\circ} \mathrm{C}$ with $25 \%$ (v/v) glycerol solution. For convenience, strain was maintained on TSA at $4{ }^{\circ} \mathrm{C}$ for temporary preservation prior to any assay. Cells were prepared by $12 \mathrm{~h}$ cultivation in TSB at $37^{\circ} \mathrm{C}(190 \mathrm{rpm})$.

\subsection{Preparation of bacterial suspension and viable cell population}

After two consecutive transfers, the bacterial cells were collected at logarithmic phase of growth by centrifugation (Refrigerated Centrifuge 2-16PK, Sigma, Germany) at 10,000 g for $3 \mathrm{~min}$ at
$4{ }^{\circ} \mathrm{C}$. The supernatant of each tube was decanted, while the cell pellets were washed three times with $0.85 \%$ (w/v) $\mathrm{NaCl}$. After washing, the cell pellets were re-suspended in flasks with different concentrations of phloretin ranging from 25 to $200 \mu \mathrm{g} / \mathrm{mL}$ and incubated at $37^{\circ} \mathrm{C}$ with shaking (190 rpm). Samples were taken for microbial enumeration at $0 \mathrm{~h}$ (immediately after incubation) and $6 \mathrm{~h}$ post-incubation. The number of viable cells was determined by plating 10 -fold serial dilutions for each sample on TSB agar and enumerating colonies after $24 \mathrm{~h}$ incubation at $37^{\circ} \mathrm{C}$. Control group without phloretin was conducted as described above.

\subsection{Potassium concentration determination}

Potassium loss from bacterial cells was determined by flame atomic absorption spectroscopy (TAS-990AFG, PERSEE, Beijing, China) according to the method of Cushnie \& Lamb (2005). The concentration of free potassium ions in bacterial suspensions was measured after the exposure of bacterial cells to phloretin at concentrations of 25 and $50 \mu \mathrm{g} / \mathrm{mL}$ for $0,0.5,1,2,3,4$ and $5 \mathrm{~h}$. Polymethylpentene conical flasks were used in this particular assay as potassium is known to absorb to glass (Howard \& Statham, 1993). The potassium ion concentration was calculated using a standard curve. Control flasks without phloretin were tested similarly. All assays were performed in triplicate.

\subsection{Measurement of adenosine triphosphate (ATP)}

The extracellular and intracellular ATP concentrations were measured using the ATP Bioluminescence Assay Kit (Beyotime, China). The assay comprised of the enzyme luciferase which catalyzes the reaction of luciferin into oxyluciferin in the presence of ATP, $\mathrm{Mg}^{2+}$ and $\mathrm{O}_{2}$, then a yellow green light is emitted. The intensity of light is proportional to the ATP content. The cells were exposed to phloretin concentrations of $25,50,100$, and $200 \mu \mathrm{g} / \mathrm{mL}$, while DMSO was used for the control. Samples were reacted at room temperature for $30 \mathrm{~min}$, centrifuged for $3 \mathrm{~min}$ at $10,000 \mathrm{~g}$, and then incubated in ice to prevent ATP loss. The ATP concentrations of supernatants, which represented the extracellular concentration, were performed according to the protocols provided by the vendor. The ATP concentrations representing intracellular content were determined by adding $500 \mu \mathrm{L}$ lysis buffer supplied by the kit to cell pellets for $5 \mathrm{~min}$ and the ATP concentration was measured with a microplate reader (Infinite M200 Pro, Tecan, Switzerland) that could detect bioluminescence.

\subsection{Release of cell constituents}

The release of cell constituents (nuclear acid and protein) into supernatant was determined as described by Zhao et al. (2015) with some modifications. Twenty milliliters of cell suspension were incubated at $37^{\circ} \mathrm{C}$ under agitation for $4 \mathrm{~h}$ in the presence of phloretin at different concentrations of 25,50 , 100 , and $200 \mu \mathrm{g} / \mathrm{mL}$. Then $2 \mathrm{~mL}$ of each sample was collected and centrifuged at 10,000 $\mathrm{g}$ for $3 \mathrm{~min}$. Control groups without phloretin treatment were tested similarly. The amount of released nuclear acid in supernatants was estimated by the detection of absorption at $260 \mathrm{~nm}$ using an UV-vis spectrophotometer (755B, JINGHUA). The protein concentration in supernatants was determined according to the Bradford's method (Bradford, 1976). 
Correction was carried out for the absorption of the suspension with $0.85 \%(\mathrm{w} / \mathrm{v}) \mathrm{NaCl}$ containing the same concentration of phloretin after 2 min reaction with tested strain, while the untreated cells were corrected with $0.85 \%$ (w/v) $\mathrm{NaCl}$.

\subsection{Electron microscope analysis of L. monocytogenes treated by phloretin}

Scanning Electron Microscopy (SEM)

Suspensions of L. monocytogenes were treated with $200 \mu \mathrm{g} / \mathrm{mL}$ of phloretin for $4 \mathrm{~h}$. The control was prepared in the absence of phloretin. After centrifugation at $10,000 \mathrm{~g}$ for $10 \mathrm{~min}$ at $4{ }^{\circ} \mathrm{C}$, the pellets were harvested and fixed with $1 \mathrm{~mL}$ glutaraldehyde $(2.5 \%, \mathrm{v} / \mathrm{v})$ overnight at $4{ }^{\circ} \mathrm{C}$. After this, the cells were dehydrated using sequential exposure per ethanol concentrations ranging from 30 to $100 \%$ and the ethanol was replaced by tertiary butyl alcohol at last. Then cells after centrifugation were dried at "critical point" in liquid $\mathrm{CO}_{2}$, and samples were gold-covered by cathodic spraying. Finally, morphology of the bacterial cells was observed on a scanning electronic microscope (S-3400N, Japan).

\section{Transmission Electron Microscopy (TEM)}

Samples were prepared as described above. The cell pellets were fixed with $1 \mathrm{~mL}$ glutaraldehyde $(2.5 \%$, v/v) overnight at $4{ }^{\circ} \mathrm{C}$. After post-fixation in $1 \% \mathrm{OsO}_{4}$, the samples were prepared by dehydration, embedding, ultrathin section, uranium and aluminum staining. The images of prepared samples were observed by a transmission electron microscopy (JEM-1230, Japan).

\subsection{Enzymes activity measurement}

Suspensions of L. monocytogenes were treated with $200 \mu \mathrm{g} / \mathrm{mL}$ of phloretin for $4 \mathrm{~h}$. The sample without adding phloretin was termed as control. Then cells from suspensions were collected by centrifugation at $10,000 \mathrm{~g}$ for $3 \mathrm{~min}$ at $4^{\circ} \mathrm{C}$. Cells were broken with $1 / 3$ volume of glass beads acid-washed $(0.425-0.6 \mathrm{~mm}$, Sigma, Beijing) by vortexing four times for $1 \mathrm{~min}$ with $1 \mathrm{~min}$ intervals in an ice bath. Cell debris and glass beads were then removed by centrifugation for $10 \mathrm{~min}\left(10,000 \mathrm{~g}, 4^{\circ} \mathrm{C}\right)$ and the supernatants were used for determination of enzyme activity.

\section{Hexokinase (HK) activity}

HK activity was determined according to Acosta et al. (2014) with minor modifications. The assay was performed in a $1 \mathrm{~mL}$ medium containing $0.1 \mathrm{M}$ Tris- $\mathrm{HCl}(\mathrm{pH} 7.4), 5 \mathrm{mM}$ $\mathrm{MgCl}_{2}, 5 \mathrm{~m} \mathrm{M}$ ATP, $4 \mathrm{~m} \mathrm{M} \mathrm{D-glucose,} 1 \mathrm{mM}$ DTT, $0.72 \mathrm{mM}$ $\mathrm{NADP}^{+}$, and $2 \mathrm{U} / \mathrm{mL}$ G6PDH. The reaction was followed by monitoring the change in absorbance at $340 \mathrm{~nm}$ due to the formation of NADPH. Enzyme activity was calculated using a molar extinction coefficient of $6.22 \mathrm{mM}^{-1} \mathrm{~cm}^{-1}$. One enzyme unit was defined as the amount catalysing the production of $1 \mu \mathrm{M}$ NADPH per min.

\section{Isocitrate dehydrogenase (IDH) activity}

IDH activity was performed as described previously (Plaut, 1969) with minor modifications. Activity assays were carried out at $25^{\circ} \mathrm{C}$ in $1 \mathrm{~mL}$ volume containing $0.1 \mathrm{M}$ Tris- $\mathrm{HCl}$ ( $\mathrm{pH} 7.4$ ), $5 \mathrm{mM} \mathrm{MnCl}_{2}, 4 \mathrm{mM}$ DL-isocitrate, $0.2 \mathrm{mM} \mathrm{NADP}^{+}$and $1 \mathrm{mM}$ DTT. The production of NADPH was recorded at $340 \mathrm{~nm}$ with an UV-vis spectrophotometer (755B, JINGHUA). Enzyme activity was calculated using a molar extinction coefficient of $6.22 \mathrm{mM}^{-1} \mathrm{~cm}^{-1}$. One enzyme unit was defined as the amount catalysing the production of $1 \mu \mathrm{M}$ NADPH per min. All the measurements for the above described enzymatic determinations were carried out in triplicate.

\subsection{Intracellular protein concentration and SDS-PAGE}

Intracellular protein concentration was measured according to Bradford (1976) after exposure to $25,50,100$, and $200 \mu \mathrm{g} / \mathrm{mL}$ phloretin for $4 \mathrm{~h}$, while the control was conducted with DMSO. Cells of bacteria were prepared and treated as described in Section 2.8.

After exposure to $200 \mu \mathrm{g} / \mathrm{mL}$ phloretin for $4 \mathrm{~h}$, samples were prepared as described above. The buffer $(20 \mu \mathrm{L}$ containing $250 \mathrm{mmol} / \mathrm{L}$ Tris-HCL pH6.8, 10\% SDS, 0.5\% bromophenol blue, $50 \%$ glycerine, $5 \% \beta$-mercaptoethanol) was added into $20 \mu \mathrm{L}$ of samples. The mixture was boiled for $5 \mathrm{~min}$ and cooled on ice. After heating in boiling-water, the samples were subjected to SDS-PAGE using a vertical electrophoresis apparatus (DYCZ$24 \mathrm{DN}, \mathrm{LY}$, Beijing). The SDS-PAGE was performed with a $10 \%$ separating gel followed by Coomassie brilliant blue $R-250$ staining and decolorizing.

\subsection{Statistical analysis}

All experiments were replicated at least three times and data were expressed as means \pm SD. Statistical analysis was performed using one-way analysis of variance (ANOVA) by Excel program at the $95 \%$ significance level to express the difference between two groups. $\mathrm{P}<0.05$ was considered statistically significant.

\section{Results}

\subsection{Measurement of viable cell population}

Bacterial viability was determined after 0 and $6 \mathrm{~h}$ incubation with phloretin at different final concentrations. The effect of phloretin on the viable counts of L. monocytogenes was shown in Figure 1. With respect to initial viable cell population of different treatment groups, we observed a $0.42 \log _{10} \mathrm{CFU} / \mathrm{mL}$ reduction at $100 \mu \mathrm{g} / \mathrm{mL}$ phloretin, and a $0.79 \log _{10} \mathrm{CFU} / \mathrm{mL}$ reduction with phloretin at a concentration of $200 \mu \mathrm{g} / \mathrm{mL}$ compared with the control. These showed an obvious decrease after the addition of phloretin at concentrations of $100,200 \mu \mathrm{g} / \mathrm{mL}$ without postincubation, while lower concentrations showed no decrease. After $6 \mathrm{~h}$ of incubation, compared with corresponding initial value, bacteria treated with phloretin at $100 \mu \mathrm{g} / \mathrm{mL}$ decreased by $1.37 \log _{10} \mathrm{CFU} / \mathrm{mL}$ and at $200 \mu \mathrm{g} / \mathrm{mL}$ by $1.74 \log _{10} \mathrm{CFU} / \mathrm{mL}$, which showed significantly bactericidal activity at higher concentrations $(\mathrm{p}<0.05)$. Unlike the obvious changing of the number of viable cells at higher concentrations, in treatments at $25,50 \mu \mathrm{g} / \mathrm{mL}$, the number of viable cells was little change. These results suggested that phloretin at final concentrations from 100 to $200 \mu \mathrm{g} / \mathrm{mL}$ could exhibit remarkable antibacterial effects within $6 \mathrm{~h}$. 


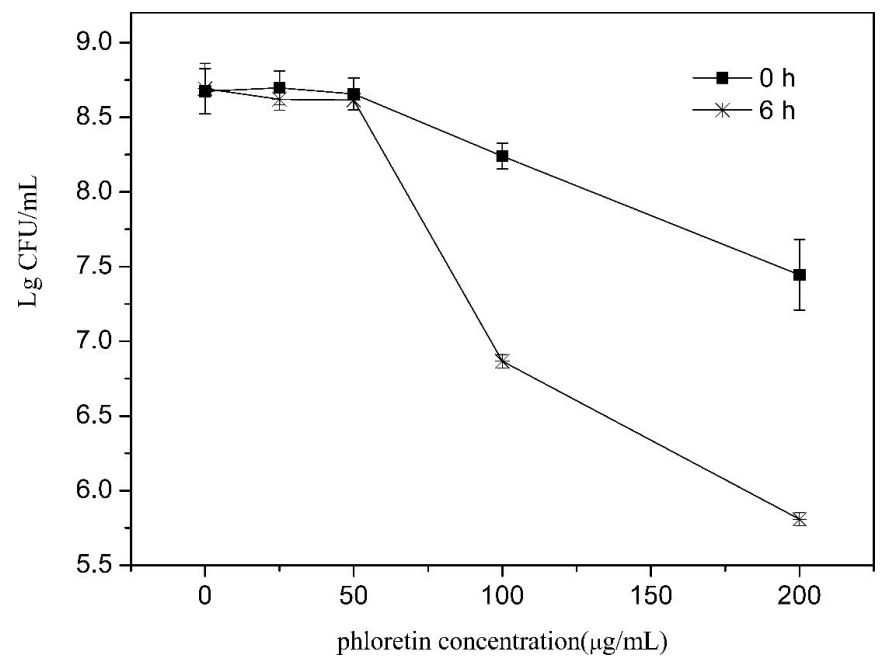

Figure 1. Growth inhibition against L. monocytogenes in different concentrations of phloretin.

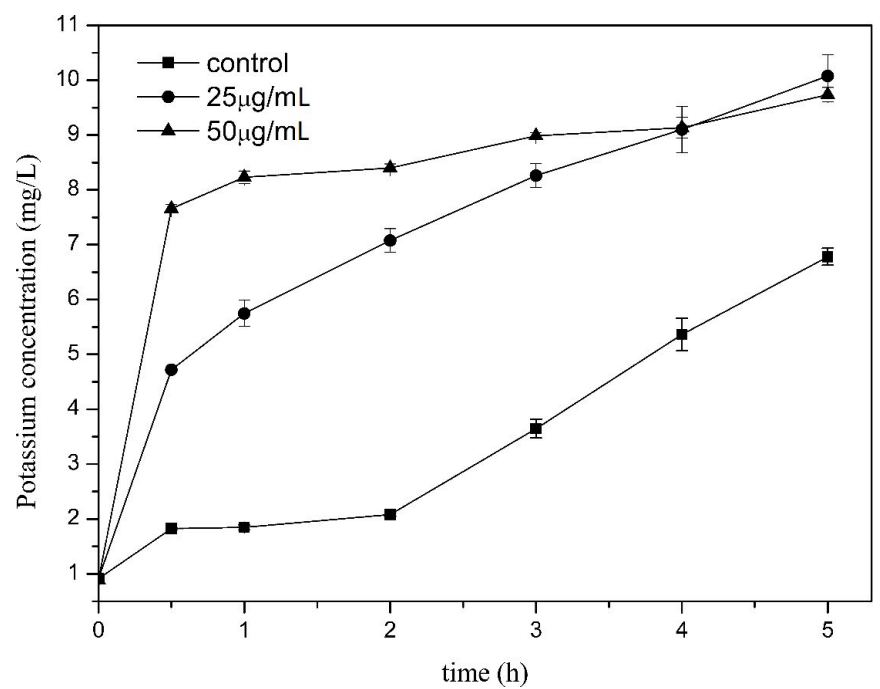

Figure 2. Effect of different concentrations of phloretin on the leakage of potassium ions from L. monocytogenes cells.

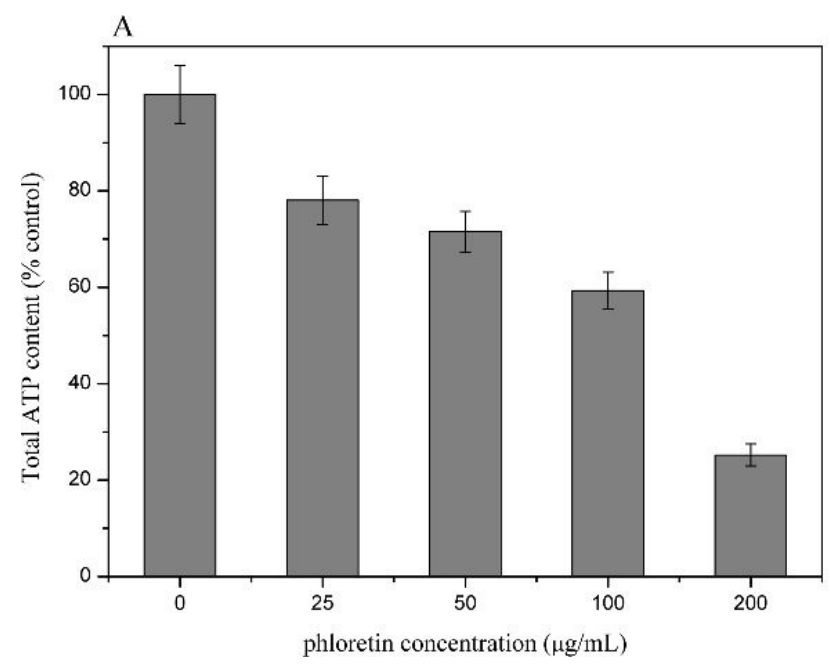

Figure 3. (A) Effect of different concentrations of phloretin on cellular total ATP content; (B) Extracellular and intracellular ATP percentage in different concentrations of phloretin.

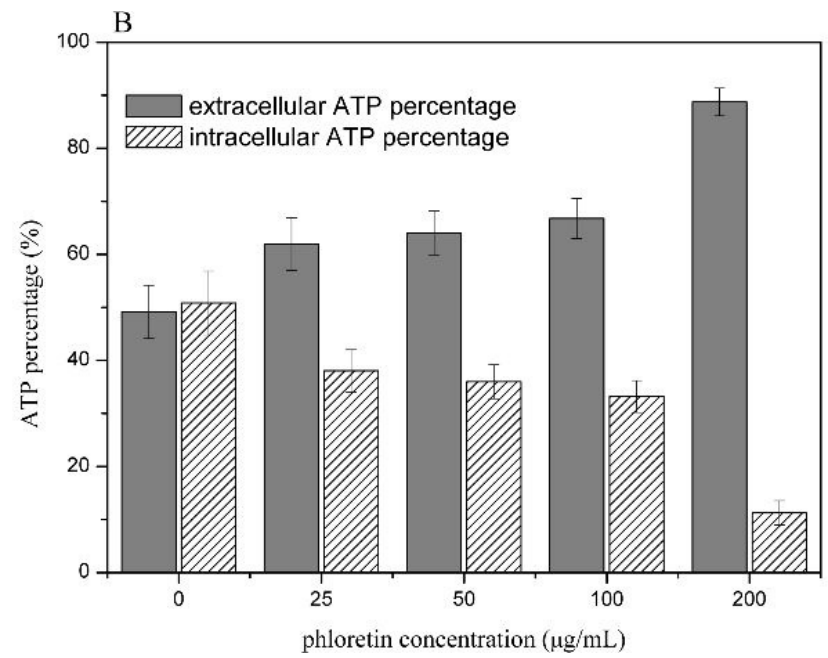

\subsection{Leakage of potassium ions}

To investigate the effect of phloretin on cell membrane permeability, we measured the leakage of potassium ions from treated cells. As observed in Figure 2, the release of potassium ions from the bacterial cells occurred immediately after the addition of phloretin at 25 and $50 \mu \mathrm{g} / \mathrm{mL}$ concentrations in the first $30 \mathrm{~min}$, while little leakage of potassium ions was observed in control cells in the same period and then the amount of $\mathrm{K}^{+}$ remained constant followed by relatively rapid increase, which may be due to normal lysis and death of bacteria. Compared to the control, the leakage of $\mathrm{K}^{+}$after 30 min treatment with phloretin at 25 and $50 \mu \mathrm{g} / \mathrm{mL}$ concentrations increased by 1.59 and 3.20 times, respectively. These results indicated that permeability of bacteria membrane would be increased to some extent, which caused the leakage of intracellular ingredient including $\mathrm{K}^{+}$. It was evident that the amount of extracellular $\mathrm{K}^{+}$ increased with increased concentration of phloretin. The result clearly meant that cell permeability was changed by phloretin.

\subsection{Measurement of adenosine triphosphate (ATP)}

To further investigate the antibacterial mode of action of phloretin, the intracellular and extracellular ATP concentrations were measured to study the effect on energy synthesis. ATP content was shown in Figure 3A as a percentage of ATP content in untreated cells. Figure $3 \mathrm{~A}$ exhibited the reduction of ATP content when Lister cells were treated with phloretin at increasing concentrations, higher concentration of phloretin leading to lower ATP content. Compared to the control, ATP content decreased by $21.92 \%, 28.45 \%, 40.69 \%$, and $74.80 \%$ after addition of phloretin at different concentrations from 25 to $200 \mu \mathrm{g} / \mathrm{mL}$, respectively. As shown in Figure 3B, the tendency of increased extracellular ATP content and decreased intracellular ATP content was observed. When cells were treated with $200 \mu \mathrm{g} / \mathrm{mL}$ phloretin, the extracellular ATP content represented $88.74 \%$ of cellular total ATP, which was 7.9 times higher than the intracellular ATP value. The above results implied that change of cytoplasmic membrane permeability might occur, which led to the losses of cell constituents. 


\subsection{Release of cell constituents}

The integrity of cell membrane was determined by the measurement of the release of cell constituents including protein and $260 \mathrm{~nm}$-absorbing material in the supernatant of tested bacteria. Compared to control, the concentration of protein and $\mathrm{OD}_{260 \mathrm{~nm}}$ in suspensions had no significant changes after adding different concentrations of phloretin to strain (data not shown). No noticeable variation could be detected with phloretin concentration values up to $200 \mu \mathrm{g} / \mathrm{mL}$, demonstrating that antimicrobial activity of phloretin might not induce membrane collapsed and cell integrity loss.

\subsection{Electron microscopy analysis}

TEM and SEM experiments were carried out to directly observe surface morphology, membrane and intracellular structure changes in Listeria cells exposed to phloretin. The TEM images (Figure 4C and 4D) showed that the control and treated cells both displayed a clearly visible outer membrane layer and compact surface without release of intracellular components and notable ruptures or pores on the cell surface. However, a remarkable electron-light region appeared in the center of the cells treated with phloretin and intracellular structure was destroyed, particularly in the nuclear region in which nuclear acid molecules distribute randomly. The cells seemed to have condensed or lost cytoplasmic materials, although the overall cell shape was still recognizable.

Meanwhile, the control cells showed unanimous electron density, suggesting that the cells are in a normal condition. Similar results assumed to be condensed DNA and cytoplasmic proteins of inactivated bacterial cells in TEM images were

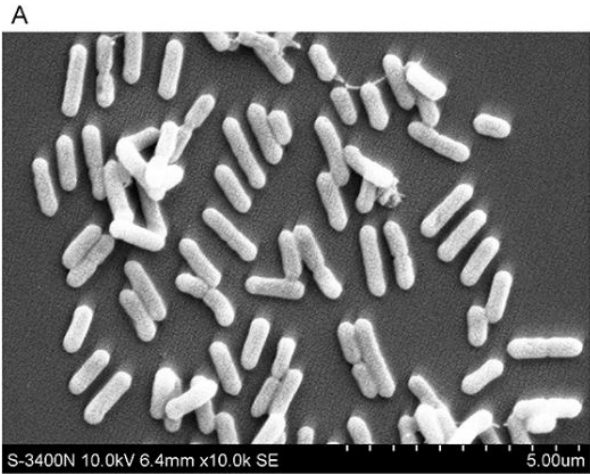

C

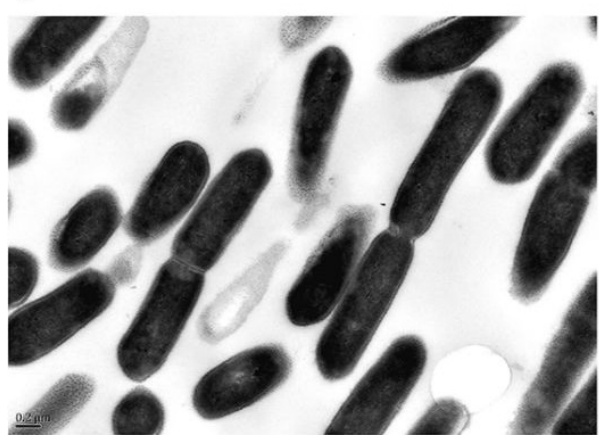

obtained after treatment by silver ions (Feng et al., 2000), polyhexamethylene guanidine hydrochloride (Zhou et al., 2010) and high hydrostatic pressure processing (Moussa et al., 2007). As regard to surface morphology of bacterial cells, SEM photomicrograph of L. monocytogenes cells treated by phloretin (Figure 4B) exhibited irregularly wrinkled outer surface, with fragmentation, adhesion and aggregation of damaged cells or cellular debris, while bacterial cells without phloretin treatment (Figure 4A) displayed typical bacilliform morphology with full and glossy surface. These changes in bacteria cells may due to lysis of cells caused by DNA aggregation.

\subsection{Enzymes activity measurements}

Another strategy for determining the mode of action of phloretin against Gram-positive bacteria was performed on the enzymatic activity of key metabolic enzymes and the results are shown in Table 1. Statistical analysis revealed that no significant difference in enzyme activity per microgram protein $(\mathrm{P}>0.05)$ was found between treated and untreated groups for the specific activities of hexokinase (HK) and isocitrate dehydrogenase (IDH). These findings demonstrated that phloretin had little effect on ability of enzyme catalyzing. Inhibition of energetic synthesis might attribute to reduction of enzyme content.

Table 1. Analytical data of Hexokinase and Isocitrate dehydrogenase activity.

\begin{tabular}{|c|c|c|c|c|c|c|c|c|}
\hline & \multicolumn{3}{|c|}{ Hexokinase } & $P$ value & $\begin{array}{r}\text { Is } \\
\text { deh }\end{array}$ & $\begin{array}{l}\text { citra } \\
\text { droge }\end{array}$ & e & $P$ value \\
\hline & \multicolumn{4}{|c|}{ (mU/mg of protein) } & \multicolumn{4}{|c|}{ (mU/mg of protein) } \\
\hline Contr & 4.04 & 4.70 & 3.70 & 0.09 & 215 & 171 & 195 & 0.59 \\
\hline phloretin & 3.75 & 3.22 & 2.88 & & 199 & 185 & 170 & \\
\hline
\end{tabular}

B

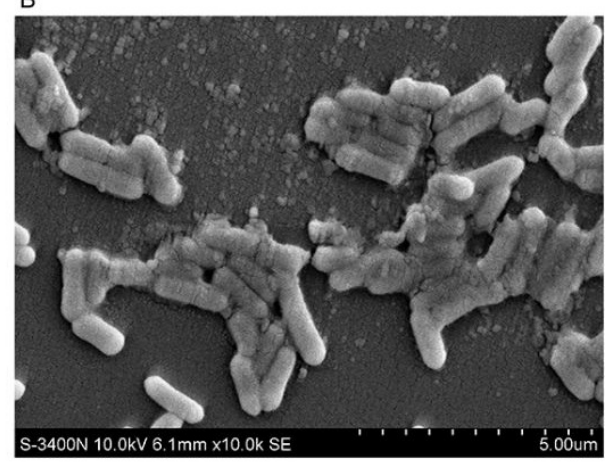

D

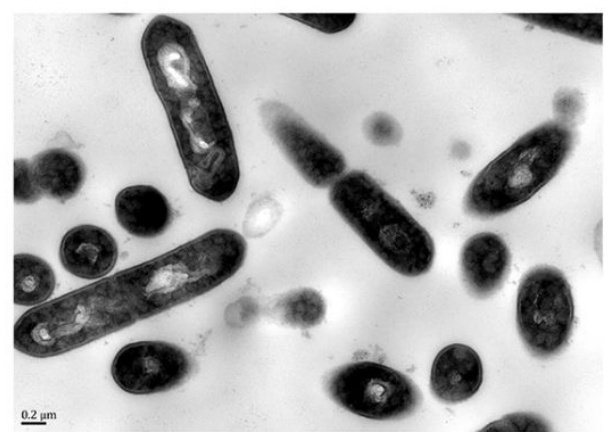

Figure 4. Scanning electron microscopy (A, B) and Transmission electron microscopy (C, D) of L. monocytogenes cells. A, C: Controls; B, D: treated by phloretin. 


\subsection{The decrease of protein synthesis and SDS-PAGE profiles}

Protein plays an important role in the life activity of bacterial cells. Statistical analysis indicated that phloretin could significantly reduce the synthesis of protein (Figure 5A). The protein concentrations exhibited a notable decrease in response to increased phloretin concentration. For the treatment groups with phloretin concentrations ranging from 25 to $200 \mu \mathrm{g} / \mathrm{mL}$, the protein concentrations decreased by $14.37 \%, 38.14 \%, 63.57 \%$, and $83.75 \%$, respectively.

SDS-PAGE profiles of bacterial soluble proteins from bacterial cells treated with phloretin are shown in Figure 5B. The protein profiles of bacteria treated with phloretin differed from those of control. The protein bands of untreated bacteria showed strong intensities. After treatment with $200 \mu \mathrm{g} / \mathrm{mL}$ for $4 \mathrm{~h}$, the protein bands faded or even disappeared. Considering no significant increasing protein contents in the cell-free supernatant confirmed by lane 3 and lane 4, it suggested that phloretin could decrease the content of cellular soluble proteins by inhibiting protein synthesis. In combination with above obtained results, it seemed to be obvious that reduction of protein synthesis resulted in the decreasing ATP biosynthesis by affecting enzyme content.

\section{Discussion}

Previous mechanism of action of flavonoid research suggested their direct antibacterial activity may be attributable to 5 aspects: cytoplasmic membrane damage, inhibition of nucleic acid synthesis, inhibition of energy metabolism, inhibition of cell wall synthesis and inhibition of cell membrane synthesis (Cushnie \& Lamb, 2011). On the basis of previous reports, this study systematically described the effect of phloretin on cells of the food-borne pathogen Listeria monocytogenes in order to elucidate its antibacterial mechanism, which were involved in integrity of cell membrane, intracellular protein content, ATP energy level, and nucleic acid morphological character.
Firstly, cell membrane structural alterations including permeability and integrity were investigated. The bacterial cytoplasmic membrane provides a permeability barrier to the passage of small ions and maintains ion homeostasis which is essential to the maintenance of normal metabolism of the cell. Therefore, the structural integrity of cell membrane is critical to bacteria growth and slight changes of cell membrane integrity can detrimentally affect cell metabolism, eventually causing cell death (Bajpai et al., 2013; Cox et al., 2001; Sharma et al., 2013; Zhang et al., 2016).

Changes in membrane integrity by antibacterial agents cause the release of intracellular components (Lee et al., 2014). As reported by Barreca et al. (2014), no significant LDH released in the broth medium from S. aureus ATCC6538, L. monocytogenes ATCC13932 and S. typhimurium ATCC13311 strains, which demonstrated that phloretin had no damage on cell membrane integrity. In order to fully illustrate the effect of phloretin on cytoplasmic membrane, we monitored the loss of $\mathrm{K}^{+}$in bacterial suspensions treated with phloretin. Leakage of potassium ions from $L$. monocytogenes increased in response to phloretin treatment, with greater exposure time and concentration resulting in increased cell leakage. Consistent with these observations, the percentage of extracellular ATP accounting for cellular total ATP increased at a phloretin concentration of $25 \mu \mathrm{g} / \mathrm{mL}$ and over (Figure 3). Absorbance at $260 \mathrm{~nm}$ for nucleic acid and determination of proteins as cell leakage markers are indicators of membrane integrity (Bajpai et al., 2013). Interestingly, the results reported here revealed no significant higher $\mathrm{OD}_{260 \mathrm{~mm}}$ and protein concentration after phloretin treatment up to $200 \mu \mathrm{g} / \mathrm{mL}$.

SEM micrographs can intuitively reflect the morphological alterations of the bacteria surface, while TEM can directly observe membrane damage and intracellular structure changes. Subsequently, the morphological alterations by SEM analysis and the membrane structural integrity by TEM analysis were investigated. Although phloretin revealed its inhibitory effect

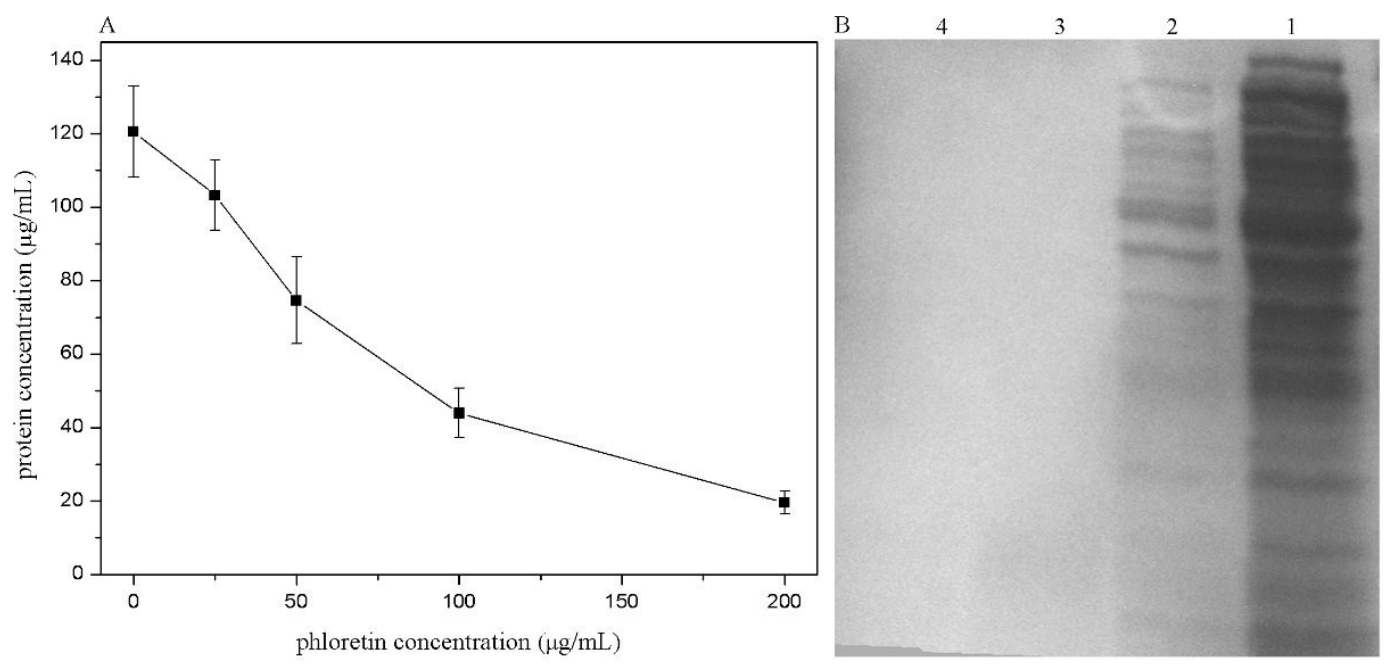

Figure 5. (A) Effect of different concentrations of phloretin on intracellular protein concentration; (B) SDS-PAGE profiles of intracellular and extracellular proteins treated with phloretin or no phloretin. Lane 1: intracellular protein concentration of untreated cells; Lane 2: intracellular protein concentration of treated cells with phloretin; Lane 3: extracellular protein concentration of untreated cells; Lane 4: extracellular protein concentration of treated cells with phloretin. 
as evidenced by the severe morphological alterations on the cell membrane and a few lysed cells in SEM images, we observed the membrane integrity still existed from TEM images. Therefore, current study presented that phloretin increased membrane permeability, but did not induce membrane damage and cell integrity loss. It is suggested that cytoplasmic membrane was probably not the main target for phloretin.

Secondly, energy metabolism as a potential target parameter to understand the mode of action of antimicrobial agents was investigated. The total ATP content showed a decreasing rate after cells exposed to phloretin at different concentrations. This might have occurred due to the reduction of ATP synthesis according to the results of metabolic enzymes activity and intracellular protein concentration.

Hexokinase is the first enzyme in the glycolytic pathway that catalyzes phosphorylation of glucose to form glucose-6phosphate (Azadbar et al., 2009). Isocitrate dehydrogenase is the key regulatory enzyme of Krebs cycle, one of the most important metabolic pathways for the generation of energy and metabolites in the living organism (Barreca et al., 2014). Their activities play a vital role in normal energetic metabolism of bacterial cells. Barreca et al. (2014) found phloretin inhibited energetic metabolism of $S$. aureus by decreasing enzymatic activity of $\mathrm{LDH}$ and IDH. However, in accordance with statistical analysis, the specific activities of HK and IDH had no significant reduction comparatively to the control. The difference of enzymatic activity might vary depending on the manner used to treat bacterial cells and the species of bacterial strain. Moreover, it was found that the protein concentration had obvious decrease caused by phloretin treatment, which suggested that phloretin inhibited energetic metabolism more likely by decreasing the enzyme content. To confirm it, the intracellular protein was further tested by SDS-PAGE and Bradford's method. SDS-PAGE profiles of bacterial soluble proteins suggested that phloretin decreased the content of cellular soluble proteins. According to reported literatures (Cloete et al., 2009; Li et al., 2014), the decrease of protein bands intensities might be that phloretin interfered with proteins synthesis of bacterial cells.

Using TEM, we found that the intracellular structure of L. monocytogenes was severely impaired by the addition of phloretin: remarkably uneven distribution of intracellular materials was observed, which was attributable to nucleic acid aggregation. Nucleic acids are involved in the transfer of cellular information including translation, transcription and DNA replication (Kohanski et al., 2010). Condensed nucleic acid would lose their abilities. On such basis, we speculated that the transcription was ceased due to DNA aggregation by phloretin treatment, thereby affecting cellular protein concentration and ATP generation. Subsequently, natural death occurred in virtue of cell metabolic disturbance, companying with leakage of intracellular constituents such as $\mathrm{K}^{+}$and ATP. Therefore, it is inferred that DNA aggregation is the key point of phloretin antibacterial mechanism. This discovery is important for future scaling up phloretin application in pharmaceutical and food industries. However, the specific mode of action and the exact targets involved in DNA aggregation still requires further study.

\section{Conclusions}

In this study, the detail antibacterial effects of phloretin on Listeria monocytogenes was characterized by viable cell population, cellular membrane permeability and skeleton integrity, energy related enzyme activity, intracellular protein determination and electron microscopy analysis. Phloretin was shown to inhibit the bacterial growth mainly through increasing cell membrane permeability and aggregating nuclear acid materials. However, the specific sites of the membrane and DNA chain where phloretin can bind with need further study. Conclusively, the findings in this study may provide a promising method for large-scale production of phloretin and a potential application of this flavonoid in antimicrobial pharmaceutical and food industry.

\section{Acknowledgements}

This research work was supported by the projects from National Natural Science Foundation of China (31972089), Shaanxi Natural Science Foundation (2019JQ-474), and the Fundamental Research Funds for the Central Universities (GK201903100).

\section{References}

Acosta, H., Cáceres, A., González-Marcano, E., Quiñones, W., Avilán, L., Dubourdieu, M., \& Concepción, J. L. (2014). Hysteresis and positive cooperativity as possible regulatory mechanisms of Trypanosoma cruzi hexokinase activity. Molecular and Biochemical Parasitology, 198(2), 82-91. http://dx.doi.org/10.1016/j.molbiopara.2015.01.003. PMid:25683029.

Alonso, V. P. P., \& Kabuki, D. Y. (2019). Formation and dispersal of biofilms in dairy substrates. International Journal of Dairy Technology, 72(3), 472-478. http://dx.doi.org/10.1111/1471-0307.12587.

Azadbar, M., Ranjbar, A., Hosseini-Tabatabaei, A., Golestani, A., Baeeri, M., Sharifzadeh, M., \& Abdollahi, M. (2009). Interaction of phosphodiesterase 5 inhibitor with malathion on rat brain mitochondrialbound hexokinase activity. Pesticide Biochemistry and Physiology, 95(3), 121-125. http://dx.doi.org/10.1016/j.pestbp.2009.08.001.

Bajpai, V. K., Sharma, A., \& Baek, K.-H. (2013). Antibacterial mode of action of Cudrania tricuspidata fruit essential oil, affecting membrane permeability and surface characteristics of food-borne pathogens. Food Control, 32(2), 582-590. http://dx.doi.org/10.1016/j. foodcont.2013.01.032.

Barreca, D., Bellocco, E., Lagana, G., Ginestra, G., \& Bisignano, C. (2014). Biochemical and antimicrobial activity of phloretin and its glycosilated derivatives present in apple and kumquat. Food Chemistry, 160, 292-297. http://dx.doi.org/10.1016/j.foodchem.2014.03.118. PMid:24799241.

Bouarab Chibane, L., Degraeve, P., Ferhout, H., Bouajila, J., \& Oulahal, N. (2019). Plant antimicrobial polyphenols as potential natural food preservatives. Journal of the Science of Food and Agriculture, 99(4), 1457-1474. http://dx.doi.org/10.1002/jsfa.9357. PMid:30206947.

Bradford, M. M. (1976). A rapid and sensitive method for the quantitation of microgram quantities of protein utilizing the principle of proteindye binding. Analytical Biochemistry, 72(1), 248-254. http://dx.doi. org/10.1016/0003-2697(76)90527-3. PMid:942051.

Chang, W.-T., Huang, W.-C., \& Liou, C.-J. (2012). Evaluation of the antiinflammatory effects of phloretin and phlorizin in lipopolysaccharidestimulated mouse macrophages. Food Chemistry, 134(2), 972-979. http://dx.doi.org/10.1016/j.foodchem.2012.03.002. PMid:23107715. 
Chávez-Martínez, A., Paredes-Montoya, P., Rentería-Monterrubio, A.-L., Corral-Luna, A., Lechuga-Valles, R., Dominguez-Viveros, J., Sánchez-Vega, R., \& Santellano-Estrada, E. (2019). Microbial quality and prevalence of foodborne pathogens of cheeses commercialized at different retail points in Mexico. Food Science and Technology, 39(Suppl. 2), 703-710. http://dx.doi.org/10.1590/fst.30618.

Cloete, T. E., Thantsha, M. S., Maluleke, M. R., \& Kirkpatrick, R. (2009). The antimicrobial mechanism of electrochemically activated water against Pseudomonas aeruginosa and Escherichia coli as determined by SDS-PAGE analysis. Journal of Applied Microbiology, 107(2), 379-384. http://dx.doi.org/10.1111/j.1365-2672.2009.04233.x. PMid:19320957.

Cox, S., Mann, C., Markham, J., Gustafson, J., Warmington, J., \& Wyllie, S. (2001). Determining the antimicrobial actions of tea tree oil. Molecules, 6(2), 87-91. http://dx.doi.org/10.3390/60100087.

Cushnie, T. P., \& Lamb, A. J. (2005). Detection of galangin-induced cytoplasmic membrane damage in Staphylococcus aureus by measuring potassium loss. Journal of Ethnopharmacology, 101(1), 243-248. http://dx.doi.org/10.1016/j.jep.2005.04.014. PMid:15985350.

Cushnie, T. P., \& Lamb, A. J. (2011). Recent advances in understanding the antibacterial properties of flavonoids. International Journal of Antimicrobial Agents, 38(2), 99-107. http://dx.doi.org/10.1016/j. ijantimicag.2011.02.014. PMid:21514796.

Feng, Q. L., Wu, J., Chen, G. Q., Cui, F. Z., Kim, T. N., \& Kim, J. O. (2000). A mechanistic study of the antibacterial effect of silver ions on Escherichia coli and Staphylococcus aureus. Journal of Biomedical Materials Research, 52(4), 662-668. http://dx.doi.org/10.1002/10974636(20001215)52:4<662::AID-JBM10>3.0.CO;2-3. PMid:11033548.

Havsteen, B. H. (2002). The biochemistry and medical significance of the flavonoids. Pharmacology \& Therapeutics, 96(2-3), 67-202. http://dx.doi.org/10.1016/S0163-7258(02)00298-X. PMid:12453566.

Howard, A. G., \& Statham, P. J. (1993). Inorganic trace analysis: philosophy and practice. Chichester: John Wiley \& Sons.

Kohanski, M. A., Dwyer, D. J., \& Collins, J. J. (2010). How antibiotics kill bacteria: from targets to networks. Nature Reviews. Microbiology, 8(6), 423-435. http://dx.doi.org/10.1038/nrmicro2333. PMid:20440275.

Lee, S.-Y., Kim, K.-B.-W.-R., Lim, S.-I., \& Ahn, D.-H. (2014). Antibacterial mechanism of Myagropsis myagroides extract on Listeria monocytogenes. Food Control, 42, 23-28. http://dx.doi. org/10.1016/j.foodcont.2014.01.030.

Li, Y. Q., Han, Q., Feng, J. L., Tian, W. L., \& Mo, H. Z. (2014). Antibacterial characteristics and mechanisms of $\varepsilon$-poly-lysine against Escherichia coli and Staphylococcus aureus. Food Control, 43, 22-27. http://dx.doi. org/10.1016/j.foodcont.2014.02.023.

MacDonald, R. E., \& Bishop, C. J. (1952). Phloretin: an antibacterial substance obtained from apple leaves. Canadian Journal of Botany, 30(4), 486-489. http://dx.doi.org/10.1139/b52-035.

Martens, E., \& Demain, A. L. (2017). The antibiotic resistance crisis, with a focus on the United States. The Journal of Antibiotics, 70(5), 520-526. http://dx.doi.org/10.1038/ja.2017.30. PMid:28246379.

Moreno, S., Scheyer, T., Romano, C. S., \& Vojnov, A. A. (2006). Antioxidant and antimicrobial activities of rosemary extracts linked to their polyphenol composition. Free Radical Research, 40(2), 223-231. http://dx.doi.org/10.1080/10715760500473834. PMid:16390832.

Moussa, M., Perrier-Cornet, J.-M., \& Gervais, P. (2007). Damage in Escherichia coli cells treated with a combination of high hydrostatic pressure and subzero temperature. Applied and Environmental Microbiology, 73(20), 6508-6518. http://dx.doi.org/10.1128/ AEM.01212-07. PMid:17766454.

Ng, K. R., Lyu, X., Mark, R., \& Chen, W. N. (2019). Antimicrobial and antioxidant activities of phenolic metabolites from flavonoid-producing yeast: Potential as natural food preservatives. Food Chemistry, 270, 123-129. http://dx.doi.org/10.1016/j.foodchem.2018.07.077. PMid:30174025.

Orhan, D. D., Özçelik, B., Özgen, S., \& Ergun, F. (2010). Antibacterial, antifungal, and antiviral activities of some flavonoids. Microbiological Research, 165(6), 496-504. http://dx.doi.org/10.1016/j.micres.2009.09.002. PMid:19840899.

Plaut, G. W. E. (1969). [8] Isocitrate dehydrogenase (DPN-specific) from bovine heart. Methods in Enzymology, 13, 34-42. http://dx.doi. org/10.1016/0076-6879(69)13012-8.

Rizvi, S. A. A., \& Saleh, A. M. (2018). Applications of nanoparticle systems in drug delivery technology. Saudi Pharmaceutical Journal, 26(1), 64-70. http://dx.doi.org/10.1016/j.jsps.2017.10.012. PMid:29379334.

Saavedra, M. J., Borges, A., Dias, C., Aires, A., Bennett, R. N., Rosa, E. S., \& Simões, M. (2010). Antimicrobial activity of phenolics and glucosinolate hydrolysis products and their synergy with streptomycin against pathogenic bacteria. Medicinal Chemistry, 6(3), 174-183. http://dx.doi.org/10.2174/1573406411006030174. PMid:20632977.

Schuh, V., Schuh, J., Fronza, N., Foralosso, F. B., Verruck, S., Vargas, A. Jr., \& Silveira, S. M. (2020). Evaluation of the microbiological quality of minimally processed vegetables. Food Science and Technology, 40(2), 290-295. http://dx.doi.org/10.1590/fst.38118.

Sharma, A., Bajpai, V. K., \& Baek, K.-H. (2013). Determination of antibacterial mode of action of Allium sativum essential oil against foodborne pathogens using membrane permeability and surface characteristic parameters. Journal of Food Safety, 33(2), 197-208. http://dx.doi.org/10.1111/jfs.12040.

Shim, S.-H., Jo, S.-J., Kim, J.-C., \& Choi, G.-J. (2010). Control efficacy of phloretin isolated from apple fruits against several plant diseases. The Plant Pathology Journal, 26(3), 280-285. http://dx.doi.org/10.5423/ PPJ.2010.26.3.280.

Vanderhaeghen, W., \& Dewulf, J. (2017). Antimicrobial use and resistance in animals and human beings. The Lancet. Planetary Health, 1(8), e307-e308. http://dx.doi.org/10.1016/S2542-5196(17)30142-0. PMid:29628162.

Wang, J., Fang, J., Wei, L., Zhang, Y., Deng, H., Guo, Y., Hu, C., \& Meng, Y. (2019a). Decrease of microbial community diversity, biogenic amines formation, and lipid oxidation by phloretin in Atlantic salmon fillets. LWT, 101, 419-426. http://dx.doi.org/10.1016/j.lwt.2018.11.039.

Wang, X., Wang, J., Wei, L., Hu, C. Y., Deng, H., Guo, Y., \& Meng, Y. H. (2019b). Apple phlorizin oxidation product 2 inhibits proliferation and differentiation of 3T3-L1 preadipocytes. Journal of Functional Foods, 62, 103525. http://dx.doi.org/10.1016/j.jff.2019.103525.

Zavareh, H. T., Ahmad, S., \& Ardestani, F. (2020). Antibacterial effects of chitosan coating containing Mentha aquatica L. essence against Escherichia coli, Staphylococcus aureus and Listeria monocytogenes in Iranian white cheese. International Journal of Dairy Technology, 73(3), 585-593. http://dx.doi.org/10.1111/1471-0307.12678.

Zhang, Y., Liu, X., Wang, Y., Jiang, P., \& Quek, S. Y. (2016). Antibacterial activity and mechanism of cinnamon essential oil against Escherichia coli and Staphylococcus aureus. Food Control, 59, 282-289. http:// dx.doi.org/10.1016/j.foodcont.2015.05.032.

Zhao, L., Zhang, H., Hao, T., \& Li, S. (2015). In vitro antibacterial activities and mechanism of sugar fatty acid esters against five food-related bacteria. Food Chemistry, 187, 370-377. http://dx.doi. org/10.1016/j.foodchem.2015.04.108. PMid:25977039.

Zhou, Z. X., Wei, D. F., Guan, Y., Zheng, A. N., \& Zhong, J. J. (2010). Damage of Escherichia coli membrane by bactericidal agent polyhexamethylene guanidine hydrochloride: micrographic evidences. 
Journal of Applied Microbiology, 108(3), 898-907. http://dx.doi. org/10.1111/j.1365-2672.2009.04482.x. PMid:19709338.

Zola, F. G., Rodrigues, A. C., Oliveira, B. D. Á., Sacramento, N. T. B., Taylor, J. G., Pinto, U. M., \& Bertoldi, M. C. (2019). Mineral and centesimal contents, antioxidant activity and antimicrobial action of phenolic compounds from Eugenia Brasiliensis Lam. Pulp. Food Science and Technology, 39(Suppl. 2), 378-385. http://dx.doi. org/10.1590/fst.18518. 